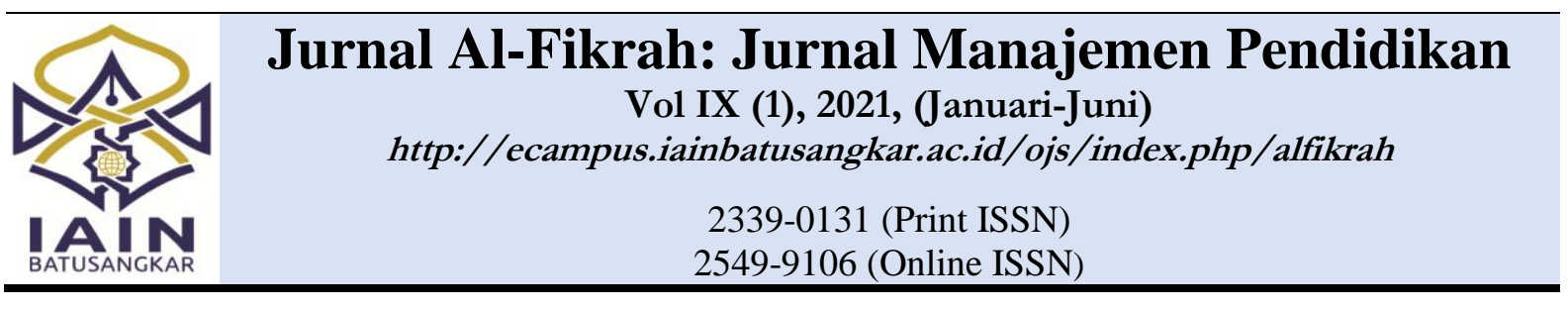

\author{
School Principal's Solution Strategy \\ on Online Learning During The Covid-19 Pandemic \\ at SDN Sumput Sidoarjo
}

\title{
Strategi Solutif Kepala Sekolah \\ Pada Pembelajaran Daring Selama Pandemi Covid 19 di SDN Sumput Sidoarjo
}

Received:30-12-2020; Revised:14-06-2021; Accepted:17-06-2021

\author{
Triana Rosalina Noor ${ }^{1 *}$, Erwin Astutik ${ }^{2}$ \\ 1,2 STAI An Najah Indonesia Mandiri \\ Korespondensi : Jl. Raya Sarirogo No. 1, Sidoarjo, Jawa Timur \\ 1email: trianasuprayoga@gmail.com, 2email: erwinastutik99@gmail.com \\ *) Corresponding Author
}

\begin{abstract}
$+20$
Abstract: This qualitative research is classified as a case study that aims to describe and analyze the principal's solution strategy for online learning during the Covid-19 pandemic at SDN Sumput Sidoarjo. The data were collected through observation, interviews with three people, namely the principal, secretary and treasurer of SDN SumputSidoarjo, and also documentary studies. Data analysis was carried out through the process of condensing data, presenting data and drawing conclusions. The results of this study showed that the Principal applied a solution strategy in the form of developing the potential of teachers through training for HR, providing online extracurricular services for students, preparing adequate learning tools for learning and optimizing the use of BOS (School Operational Funds). The obstacles faced in implementing the principal's strategies and solutions for learning during the Covid 19 pandemic were the human resource factors, heterogeneity of student guardians, limited funds and communication. In response to this, the Principal has taken a policy to develop HR competencies, relax financial financing and open a two-way communication forum between parents and schools.
\end{abstract}

Keywords: Solution Strategies, Online Learning, Principal, Covid-19 Pandemic

Abstrak: Penelitian ini tergolong penelitian kualitatif studi kasus yang bertujuan untuk
mendeskripsikan dan menganalisis strategi solutif Kepala Sekolah pada pembelajaran daring
selama pandemi Covid 19 di SDN Sumput Sidoarjo. Proses pengumpulan data menggunakan
observasi, wawancara kepada tiga orang yaitu kepala sekolah, sekretaris dan bendahara SDN
Sumput Sidoarjo, serta studi dokumentasi. Analisis data dilakukan melalui proses kondensasi
data, penyajian data dan penarikan kesimpulan. Hasil penelitian ini adalah Kepala Sekolah
mengambil langkah pengembangan potensi para guru melalui pelatihan-pelatihan bagi SDM,
penyediaan layanan ekstrakulikuler online bagi peserta didik, mempersipakan perangkat
pembelajaran yang memadai pembelajaran dan optimalisasi penggunaan dana BOS. Adapun 
kendala yang dihadapi pada implementasi strategi solutif kepala sekolah pada pembelajaran daring saat pandemi Covid 19 adalah faktor SDM, heterogenitas wali murid, keterbatasan dana dan komunikasi. Menyikapi hal tersebut, strategi solutif Kepala Sekolah melalui pengambilan kebijakan untuk pengembangan kompetensi SDM, relaksasi pembiayaan keuangan serta membuka melalui forum komunikasi dua arah antara wali murid dan sekolah.

Kata Kunci: Strategi solutif, Pembelajaran Daring, Kepala Sekolah, Pandemi Covid-19

\section{PENDAHULUAN}

$\mathrm{P}$ andemi covid-19 yang terjadi sejak akhir tahun 2019 memberikan dampak pada setiap segmen kehidupan manusia, seperti ekonomi, sosial, pariwisata dan tidak terkecuali pada sektor pendidikan. Pendidikan yang sebelum terjadi pandemi Covid 19 dilakukan melalui sistem konvensional tatap muka, maka sejak terjadinya pandemi harus berubah menjadi sistem dalam jaringan (daring). Kementrian Pendidikan dan Kebudayaan menetapkan bahwa selama masa pandemi Covid 19 ini, setiap satuan pendidikan diarahkan untuk melakukan pembelajaran melalui sistem belajar dari rumah dengan harapan agar dapat melindungi dan mencegah dampak buruk dari penularan Covid 19 di lingkungan pendidikan (Kemendikbud, 2020).

Melalui peralihan proses pembelajaran di tiap satuan pendidikan dari tatap muka ke daring atau PJJ (pembelajaran jarak jauh), bertujuan agar pembelajaran tetap bisa berjalan dan tetap bisa memberikan pengalaman belajar yang bermakna bagi peserta didik. Pembelajaran daring hendaknya dilakukan tanpa membebani peserta didik untuk menuntaskan seluruh capaian pembelajaran yang telah ditetapkan agar dapat dilakukan dengan pembelajaran yang bervariasi. Desain pembelajaran daring disesuaikan dengan kondisi, minat dan ketersediaan fasilitas yang dimiliki oleh seluruh jenjang pendidikan mulai dari tingkat pendidikan usia dini, dasar, menengah dan pendidikan tinggi (Kemendikbud, 2020).

Pembelajaran pada masa pandemi Covid 19, menuntut setiap satuan pendidikan untuk tetap bisa produktif dan kreatif agar proses pembelajaran tetap berjalan dengan tersistem dengan baik, bukan hanya pada aspek pengetahuan namun juga karakter peserta didik. Pendidikan yang tersistem dengan baik akan membantu optimalisasi intelektual dan pengembangan kepribadian dari peserta didik (Noor, 2019). Namun melaksanakan pembelajaran pada masa pandemi Covid 19 ini tidaklah mudah. Sistem pembelajaran daring yang diarahkan oleh Kemendikbud menjadi tantangan tersendiri bagi setiap unit pendidikan dalam penerapannnya. Pembelajaran daring adalah pembelajaran yang menggunakan media telekomunikasi seperti smartphone ataupun laptop sehingga menjadi sebuah tuntutan ekstra bagi sekolah. Hal ini dikarenakan unit pendidikan baik itu pihak sekolah dan peserta didik belum terbiasa dengan sistem daring ini (Utami et al., 2020). Selain itu ketersediaan jaringan internet yang memadai, pengadaan gadget yang tidak mendukung, pengelolaan, penilaian yang tidak maksimal dan minimnya pengawasan menjadi permasalahan yang terjadi saat pembelajaran daring diterapkan (Rigianti, 2020).

Pembelajaran daring yang dilakukan berdasarkan Surat Edaran (SE) Mendikbud No 4 Tahun 2020 membawa dampak yang cukup serius bagi peserta didik. Pembelajaran yang awalnya secara konvensional tatap muka dengan peserta didik membawa perubahan pada pembelajaran daring yang memunculkan masalah baru pada tingkat pemahaman peserta didik. Pembelajaran daring memungkinkan para peserta didik mengalami ketidakpahaman atas materi yang diberikan oleh guru sehingga menyebabkan miskonsepsi atas materi yang dipaparkan. Selain itu kekhawatiran orang tua atas kejenuhan anaknya atas tugas yang diberikan oleh guru selama pembelajaran daring juga menjadi hal yang patut 
dipertimbangkan untuk dicarikan solusi (Khairuddin, 2020).

Kondisi pembelajaran daring yang bermasalah juga terjadi di SDN Sumput, Sidoarjo. Pembelajaran daring yang diterapkan dirasakan belum optimal dan terkendala beberapa hal. Kendala yang dialami diantaranya adalah keluhan kuota internet yang mahal dan jaringan yang tidak memadai, sehingga penerimaan informasi dari sekolah ke wali murid tidak seluruhnya diterima dengan baik. Selain itu, kondisi gadget wali murid yang tidak memadai, oleh karena hanya memiliki satu gadget yang dipakai untuk semua anak ataupun dipakai oleh orang tuanya bekerja. Hal tersebut membuat sekolah harus berpikir secara khusus, karena permasalahan di tiap kelas berbedabeda dan semua membutuhkan solusi yang cepat dan tepat (W/ Kepsek/ SDN Sumput/ 17-12-2020).

Adanya tuntutan-tuntutan inovasi terkait pembelajaran daring menjadi hal yang penting untuk ditindaklanjuti oleh satuan pendidikan, khususnya kepala sekolah. Kepala sekolah dituntut untuk mencari penyelesaian yang tepat agar fungsi sekolah tetap berjalan. Kepala sekolah merupakan faktor penting yang paling menentukan optimal tidaknya sebuah lembaga pendidikan, oleh karena kepala sekolah merupakan seorang pemimpin, motor penggerak dan penentu kebijakan di sebuah lembaga pendidikan (Wahyudi, 2012). Pemimpin merupakan seseorang yang memiliki kemampuan untuk menggerakkan, mengarahkan, memberi perintah, memberi solusi sekaligus mempengaruhi pola pikir dari setiap bawahan agar tercapai tujuan yang telah ditetapkan (Rusdiana, 2016). Kemampuan tersebut sangatlah diperlukan dalam menghadapi situasi-situasi yang terjadi di sebuah lembaga pendidikan sebagaimana halnya kondisi pandemi Covid 19 seperti sekarang.

Pembelajaran saat pandemi Covid 19 ini merupakan sebuah permasalahan yang harus dicarikan pemecahannya. Kepala sekolah akan menggunakan kemampuan kognitifnya untuk bisa mengatasi permasalahan melalui keputusan yang diambil, dan pada proses pengambilan keputsan tersebut akan melibatkan beberapa kemungkinankemungkinan untuk dijadikan sebagai solusi permasalahan (Indrawijaya, 2000). Pengambilan keputusan saat pandemi Covid 19, terkait pengembangan pembelajaran daring yang tepat merupakan sebuah keputusan yang memang harus cepat agar kendala-kendala segera teratasi (Hidayatullah et al., 2020). Strategi merupakan sebuah tindakan sistematis yang diambil oleh manajemen untuk mengkondisikan organisasi untuk bisa mencapai tujuan. Strategi dirumuskan secara bersama-sama dengan semua komponen yang ada di sebuah organisasi. Artinya setiap strategi yang dihasilkan bukan semata-mata kehendak pribadi pimpinan melainkan kehendak bersama mengakomodasi kebutuhan publik (Sagala, 2013).

Mencermati kondisi tersebut, penelitian ini mencoba untuk mendeskripsikan strategi dan solusi seorang kepala sekolah dalam pembelajaran daring yang diterapkan di SDN Sumput Sidoarjo.

\section{METODE}

Penelitian ini dilakukan di SDN Sumput Sidoarjo, yang beralamatkan di Jl. Raya Sumput, Kab. Sidoarjo. Penelitian ini menggunakan pendekatan kualititatif dengan jenis studi kasus, yaitu peneliti mencari data, mengambil dan menginterpretasikan data dari suatu kegiatan yang terjadi di sebuah tempat tertentu (Ghony \& Almanshur, 2017).

Informan penelitian pada penelitian ini dipilih secara purposive, yakni dengan memilih berdasarkan kriteria yang telah ditetapkan (Sugiyono, 2016a). Informan penelitian ini ada kepala sekolah, sekretaris dan bendahara sekolah, oleh karena dianggap paling tahu atas kondisi yang terjadi di SDN Sumput Sidoarjo.

Adapun teknik pengumpulan data yanag digunakan peneliti adalah menggunakan tiga teknik yaitu wawancara mendalam (Indepth Interview), observasi partisipan (Partisicipant Observation) dan studi dokumen. Teknik yang digunakan dalam wawancara adalah wawancara 
tidak terstruktur, yaitu suatu proses wawancara yang tidak menggunakan pedoman wawancara yang telah tersusun secara sistematis dan lengkap untuk pengumpulan datanya. Pada saat proses wawancara, peneliti dibantu dengan melakukan catatan pada buku kecil, alat perekam dan kamera. Hal tersebut bertujuan agar hasil wawancara dapat tersimpan dengan baik untuk dapat digunakan pada proses berikutnya (Sugiyono, 2016b).

Data yang telah didapatkan dari kelima informan tersebut untuk selanjutnya dianalisis secara tunggal. Pada tahap ini, peneliti menelaah seluruh data yang telah terkumpul dari observasi, wawancara, dan telaah dokumen dengan menggunakan teknik analisis dari Miles dan Huberman yaitu membagi kegiatan analisis menjadi tiga bagian yaitu kondensasi data, penyajian data dan penarikan kesimpulan (Miles, Huberman \& Saldana, 2014).

\section{HASIL DAN PEMBAHASAN}

\section{Kepala Sekolah Dan Pembelajaran Daring} Selama Pandemi Covid 19

Kepala sekolah merupakan pemimpin sebuah lembaga pendidikan formal yang memiliki tugas dan tanggung jawab yang besar dalam keberlangsungan lembaga yang dipimpinnya. Kepala sekolah merupakan motor penggerak yang akan menentukan bagaimana tujuan sekolah agar dapat direalisasikan. Sebagai pemimpin formal, kepala sekolah bertanggung jawab akan tercapainya tujuan pendidikan melalui upaya pemberdayaan seluruh masyarakat sekolah (Wahyudi, 2012). Kepala sekolah memiliki fungsi strategis sebagai pengontrol aktivitas yang berjalan di sebuah lembaga pendidikan (Dedi, 2019).

Kepala sekolah memiliki fungsi dalam penciptaan dan pencapaian iklim pembelajaran yang efektif. Nawawi menyebutkan bahwa kepala sekolah memiliki fungsi pokok yang harus dijalankan yakni fungsi instruktif, konsultatif, partisipasi, delegasi dan pengendalian (Rusdiana, 2016). Pada kondisi pandemi Covid 19 ini, fungsi tersebut menjadi jelas terlihat dan semakin kuat diterapkan oleh kepala sekolah sebagai seorang manajer yang profesional.

\section{Fungsi Instruktif}

Saat pandemi Covid 19, kepala sekolah menginstruksikan untuk melakukan semua pembelajaran secara daring sebagaimana arahan dari pihak pusat. Kepala sekolah memerintahkan agar para guru melakukan pembelajaran melalui zoom, videocall atau google meet agar proses pembelajaran tetap berjalan lancar.

Fungsi instruktif adalah kepala sekolah sebagai komunikator, yakni menentukan keputusan untuk dilaksanakan oleh semua orang yang dipimpin terkait apa, bagaimana, kapan dan dimana keputusan tersebut harus dilaksanakan (Rusdiana, 2016). Instruksi kepala sekolah ini akan menjadi arahan kepada guru untuk mengelola kelas dengan baik dalam rangka mencapai target pembelajaran di sekolah (Saifulloh \& Darwis, 2020), oleh karena sudah menjadi tanggung jawab kepala sekolah untuk memberikan perintah dan informasi secara formal kepada bawahannya (Sagala, 2013).

2. Fungsi Konsultatif

Pada kondisi pandemi Covid 19, kepala sekolah memberi masukan kepada para guru terkait pembelajaran daring yang dilakukan. Pertimbangan yang diberikan bersifat kasuistik sehingga pertimbangannya tidak diberikan langsung secara menyeluruh. Hal ini dikarenakan kondisi peserta didik, usia, latar belakang keluarga menjadi data pendukung dalam memberikan pertimbangan.

Fungsi konsultatif merupakan usaha seorang kepala sekolah dalam memberikan pertimbangan kepada orang-orang yang dipimpinnya (Rusdiana, 2016). Kepala sekolah memiliki peran yang penting dalam menyelesaian kesulitan yang dialami oleh guru dala proses pembelajaran (Irtiqo, 2017). Adanya konsultasi dengan orang-orang yang dipimpin seorang pemimpin bisa dijadikan sebagai masukan 
atas kebijakan-kebijakan yang telah ditetapkan sebelumnya (Wahyudi, 2012).

3. Fungsi Partisipasi

Kepala sekolah ikut aktif dalam perumusan program-program pembelajaran yang diterapkan selama pandemi Covid 19. Kepala sekolah berusaha mengaktifkan orang-orang yang dipimpinnya agar tetap termotivasi untuk produkti.

Fungsi partisipasi menunjukkan bahwa seorang kepala sekolah merupakan bagian dari kegiatan yang dijalankan di sekolah. Kepala sekolah juga merupakan bagian dari kesatuan dari sekolah yang memiliki tugas-tugas sesuai dengan porsinya masing-masing (Rusdiana, 2016). Kepala sekolah meskipun sebagai pemimpin, tetap memposisikan diri sebagai bagian dari pelaksana tugas-tugas yang ada di lembaga pendidikan (Murniati, 2008).

4. Fungsi Delegasi

Pada pembelajaran daring, kepala sekolah memberikan keleluasaan kepada guru untuk mendesain pembelajaran daring yang menarik bagi peserta didik. Keleluasaan yang diberikan kepada guru dalam pembelajaran daring mengacu pada instruksi yang telah diberikan kepala sekolah sebelumnya.

Fungsi delegasi yang diberikan kepala sekolah kepada guru merupakan bentuk pengembangan diri yang ingin dibentuk oleh kepala sekolah kepada bawahannya dan menempatkan guru sebagai pribadi yang profesional dalam proses pendidikan (Sagala, 2013).

5. Fungsi Pengendalian

Pada pembelajaran daring, kepala sekolah tetap mengontrol aktivitasaktivitas yang dilakukan oleh para guru agar tetap terarah. Kepala sekolah akan mengkoreksi ataupun tidak segan mengubah kebijakan yang diambil saat di lapangan terjadi ketidaksesuaian.

Fungsi pengendalian ini menjadi penting karena dapat mengukur keberhasilan sebuah program yang telah dilaksanakan. Pengendalian ini akan membawa pada suatu strategi tepat sasaran guna menyelesaikan permasalahan yang dialami sebuah lembaga pendidikan (Rohmah, 2017).

\section{Strategi dan Solusi Kepala Sekolah Pada Pembelajaran Daring Selama Pandemi Covid 19}

Melakukan proses pembelajaran secara daring bukanlah sebuah perkara yang mudah. Banyak kendala-kendala yang dihadapi agar proses transfer of knowledge tetap bisa dilakukan. Dibutuhkan sebuah perencanaan yang sistematis agar pelaksanaan pembelajaran bisa mendapatkan hasil yang optimal melalui menjalankan fungsi manajemen yang tepat (Noor, 2017b). Banyak hal dan upaya yang harus dipikirkan dan dilakukan agar tujuan pembelajaran daring bisa tercapai. Tingkat keberhasilan suatu proses pendidikan di sebuah lembaga pendidikan akan bergantung pada keberhasilan kepala sekolah dalam menentukan strategi dan solusi atas permasalahan yang terjadi.

Adapun beberapa strategi dan solusi yang diambil oleh kepala SDN Sumput Sidoarjo adalah sebagai berikut:

1. Pendidikan dan pelatihan guru melalui pelatihan online

Salah satu kendala dari pelaksanaan pembelajaran daring di SDN Sumput Sidoarjo adalah kemampuan teknologi informasi dari para guru dan tenaga kependidikan yang belum maksimal. Para guru dan tenaga kependidikan belum sepenuhnya melek atas fitur-fitur digital yang pada pembelajaran daring digunakan sebagai media pembelajaran. Para guru dan tenaga kependidikan sudah terbiasa dengan pembelajaran konvensional tatap muka yang tidak banyak melibatkan teknologi didalamnya. Oleh karena sudah menjadi tuntutan, para guru difasilitasi oleh pigak sekolah untuk mengikuti rangkaian pelatihan teknologi informasi secara online. Pelatihan ini bertujuan agar para guru 
setidaknya mengetahui berbagai macam media pembelajaran online yang bisa digunakan selama pandemi Covid 19.

Pelatihan merupakan sebuah kebijakan dari pihak top management sebuah organisasi untuk meningkatkan kualitas sebuah organisasi. Jika pelatihan tidak difasilitasi oleh top management maka iklim kerja yang baik tidak akan tercapai (Mangkuprawira, 2003). Pelatihan menjadi salah satu strategi dalam meningkatkan kinerja sebuah lembaga pendidikan (Osreni, 2020). Pelatihan dan pengembangan kompetensi dari seorang karyawan sangat penting dan merupakan tuntutan kemajuan teknologi dan persaingan organisasi dan akan menjadi sebuah investasi jangka panjang. Adapun yang penting dikembangkan adalah bukan hanya kecakapan secara teori tapi juga keterampilan praktis yang akan membuat pekerjaannya menjadi lebih efisien dan efektif (Hasibuan, 2012). Pelatihan berkelanjutan penting sebagai wujud peningkatan kualitas organisasi, dan kurangnya pelatihan menjadi salah satu faktor kegagalan mutu sekolah (Fattah, 2013).

2. Keikutsertaan guru dalam kegiatan Peningkatan Profesionalan Berkelanjutan (PKB) online

Sebagai tindak lanjut dari usaha peningkatan mutu guru selain melalui pelatihan-pelatihan, kepala SDN Sumput memiliki kebijakan peningkatan mutu guru melalui program PKB. Kepala sekolah mewajibkan guru untuk ikut serta dalam program ini sebagai usaha untuk meningkatkan standar kompetensi guru. Program PKB ini merupakan program dari Kemendikbud, dan sebelum pandemi Covid 19 pun para guru sudah mengikutinya. Hanya saja perbedaanya, saat pandemi Covid 19 ini, kepala sekolah semakin menekankan betapa pentingnya peningkatan mutu guru.

Program PKB ini sangat penting dalam rangka pengembangan diri guru agar menjadi lebih baik dalam hal kompetensi. Program ini memiliki beberapa tujuan yakni memberikan bantuan kepada guru secara efektif untuk mencapai standart yang lebih tinggi dalam mengemban tugasnya sebagai seorang guru, memberikan motivasi dan kontribusi positif bagi etos kerja guru, mewujudkan tanggung jawab guru profesional untuk meningkatkan keprofesionalannya dan menciptakan masyarakat untuk dapat belajar sepanjang hayat (Rusdarti et al., 2019). Pada program PKB nilai uji kompetensi bisa menjadi gambaran sejauh mana capaian minimal yang telah dicapai oleh seorang guru terkait fungsi tugasnya dalam pendidikan dan pengajaran (Maiza \& Nurhafizah, 2019). Kompetensi guru yang tercermin pada sebuah situasi belajar yang baik akan mempengaruhi peserta didik untuk bisa berinteraksi dengan guru secara intensif (Sagala, 2013). PKB online menjadi alternative yang dapat diikuti oleh guru dalam meningkatkan mutu saat pandemi covid-19.

3. Pengembangan literasi digital

Pandemi Covid 19 ini betul-betul membawa perubahan dalam pendidikan. Kepala SDN Sumput semakin aware dengan pentingnnya pengembagan literasi para guru. Guna meningkatkan minat guru untuk belajar, disediakanlah fasilitas bacaan untuk menambah wawasan guru untuk bekal mengajar peserta didik. Program literasi digital dilakukan dengan cara menyedikan berbagai e-book di google drive sekolah sehingga dapat diakses dari mana saja untuk dapat menunjang proses mengajar guru didalam kelas. Selain itu kepala sekolah juga memfasilitasi guru dalam hal peralatan dan fasilitas digital berikut tutorial tata cara mengakses, menggunakan, menganalisis dan mensintesis sumber-sumber digital yang ada.

Adanya pemberian fasilitas dari kepala sekolah kepada guru merupakan bentuk memanusiakan manusia. Hal tersebut akan memotivasi guru untuk terus meningkatkan 
kemampuannya untuk memberikan layanan belajar dan bekerja secara profesional (Sagala, 2013). Penguatan literasi digital ini hal yang mutlak dilakukan saat pandemi Covid 19, oleh karena satuan pendidikan melakukan pendidikan berbasis virtual classroom sehingga capaian pembelajaran bisa maksimal (Nahdi \& Jatisunda, 2020).

4. Penyediaan kegiatan ekstrakurikuler online untuk peserta didik

Meskipun pembelajaran melalui daring, tidak menyurutkan kreatifitas kepala SDN Sumput untuk juga mendesain kegiatan ekstrakurikuleruntuk peserta didik secara online. Kepala SDN Sumput tetap menyediakan layanan ekstrakulikuler bagi siswa saat pandemi covid-19 berupa ekstrakulikuler online. Kegiatan ekstrakulikuler online dibatasi oleh kegiatan yang hanya dapat dilakukan dengan cara sederhana, seperti kegiatan ekstrakurikuler pramuka dan kaligrafi. Adapun kegiatan ekstrakurikuler yang membutuhkan interaksi fisik antara pelatih dan peserta didik ditiadakan sampai kondisi pandemi Covid 19 cukup kondusif. Kegiatan ekstrakurikuler merupakan kegiatan yang penting untuk mengasah bakat dan minat peserta didik. Meskipun kondisi pandemi membuat beberapa kegiatan ekstrakurikuler terhenti, namun masih ada sisi lain yang bisa dikembangkan dari diri peserta didik melalui ekstrakurikuler online. Kegiatan yang diberikan melalui stimulasi-stimulasi program yang diberikan oleh pihak sekolah dan untuk selanjutnya ditindaklanjuti dengan melakuan aktivitas pengamatan dan kegiatan di rumah masing-masing oleh setiap peserta didik. Kegiatan esktrakurikuler penting untuk meningkatkan kematangan sosial peserta didik (Firdaus \& Aslinda, 2021).

Kegiatan pengamatan mandiri yang dilakukan oleh peserta didik bermanfaat guna mengasah kepekaan terhadap lingkungan. Peserta didik dirangsang untuk merespon atas apa yang terjadi di lingkungan sekitarnya. Makin banyak daya reaksi seorang peserta didik terhadap lingkungan maka akan semakin banyak respon dan daya analisis yang dimiliki (Ahmadi \& Supriyono, 2008). Hal ini berkaitan dengan pada dasarnya lingkungan akan menstimulasi perilaku dan persepsi dari manusia atas lingkungannya (Noor, 2017a). Selain itu guru juga bisa menyampaikan nilai-nilai kehidupan kepada peserta didik pada proses pembelajaran, khususnya pembelajaran yang dikemas melalui ektrakurikuler. Nilai-nilai tersebut akan mengarahkan peserta didik untuk dekat dekat dengan lingkungan yang akan menjadi pengalaman belajar tersendiri bagi peserta didik (Noor, 2017c).

5. Mengikutsertakan peserta didik pada perlombaan online

Agar tetap meningkatkan daya kreatifitas, sifat kompetitif dan daya fikir kritis peserta didik saat pandemi covid-19, ajang perlombaan online menjadi salah satu alternatif yang dipilih oleh kepala sekolah. Kepala SDN Sumput tetap optimis melalui perlombaan online yang diikuti oleh peserta didiknya akan membawa penyegaran dalam proses belajar daring. Peserta diarahkan untuk tetap memiliki semangat berkompetisi baik itu terkait kemampuan akademik ataupun non akademik agar tidak menjadi generasi yang pasif dan statis.

Melalui ajang perlombaan, peserta didik diajak untuk mengasah daya kreativitasnya agar bisa mensistesis fungsi thinking, feeling, sensing dan intuiting yang dimiliki. Perlombaan yang menstimulasi daya potensi yang dimiliki peserta didik diharapkan dapat meningkatkan rasa ingin tahu atas hal-hal baru yang ada di lingkungannya (Asrori, 2009)

6. Melakukan pembelajaran melalui modul dan home visit

Kepala SDN Sumput menyadari dan memahami bahwa peserta didik yang bersekolah di lembaganya berasal dari latar belakang keluarga yang berbeda-beda. Perbedaan daalam hal ekonomi, pendidikan orang tua bahkan budaya. Hal tersebut 
menyebabkan kepala sekolah membuat kebijakan pembelajarn dengan sistem home visit untuk kategori anak-anak tertentu. Terkait latar belakang ekonomi, latar belakang wali didik berasal dari ekonomi menengah kebawah, sehingga banyak tidak sedikit peserta didik yang yang kesulitan untuk mengikuti pembelajaran daring. Kondisi ini disebabkan oleh sarana penunjang seperti smartphone dan alat peendukung pembelajaran lainnya yanag tidak memadai. Menyikapi permasalahan tersebut membuat kepala sekolah berinisiatif untuk membolehkan siswa belajar melalui modul atau tugas yang telah dibuat guru terkait materi pembelajaran di sekolah. Bagi yang mengalami kesulitan dalam belajar, pihak sekolah menugaskan guru untuk melakukan home visit secara berkala ke rumah peserta didik.

Mengolah bahan belajar saat pembelajaran daring memang menjadi masalah tersendiri bagi peserta didik. Peserta didik mengalami kesulitan dalam menerima isi pelajaran sehingga informasi yang diberikan tidak mengenai sasaran. Permasalahan ini bisa teratasi salah satunya dengan cara pengelolaan bahan ajar yang menstimulasi peserta didik untuk aktif belajar, seperti memberikan modul. Setelahnya, guru akan menindaklanjuti keaktifan peserta didik tersebut melalui proses inkuiri atas materi yang diberikan (Dimyati \& Mudjiono, 2015). Bahan ajar yang disiapkan dalam bentuk bacaan akan mepermudah peserta didik untuk mendapatkan insight (Noor, 2020b).

7. Melakukan perpanjangan deadline tugas harian

Salah satu kendala pembelajaran daring adalah terbatasnya gadget yang dimiliki oleh wali murid, baik itu dikarenakan oleh dibawa orang tua bekerja atau jumlahnya terbatas dan digunakan bersamaan dengan saudara-saudaranya yang juga melakukan pembelajaran daring. Terdapat beberapa keluarga siswa yang hanya memiliki satu bandphone dalam satu keluarga dan orangtuanya bekerja diluar rumah sehingga harus menunggu orangtuanya pulang untuk dapat mengerjakan tugas sekolah. Mencermati kondisi tersebut, kepala sekolah memberikan instruksi untuk guru agar memberikan kelonggaran bagi siswa dalam mengumpulkan tugas harian, sehingga peserta didik bisa mengumpulkan tugas setelah orangtuanya pulang atau setelah bergantian dengan saudaranya.

Tugas merupakan salah satu bentuk kegiatan evaluasi dari proses pembelajaran yang telah dilakukan. Capaian pembelajaran peserta didik akan diketahui melalui penguasaan atas materi yang diberikan oleh guru. Suatu pembelajaran yang inovatif dan menyenangkan adalah manakala terjalin komunikasi multi arah, sehingga antara guru dan peserta didik terjalin keterbukaan terkait kendala yang dialami. Melalui komunikasi multi arah tersebut, guru bisa menentukan bentuk bimbingan atau tindaklanjut apa yang harus dilakukan pada peserta didik (Syah, 2016). Keterbukaan merupakan sebuah bentuk adanya dinamisasi dari sebuah proses komunikasi (Noor, 2020a).

8. Optimalisasi penggunaan dana Biaya Operasional Sekolah (BOS)

Kendala yang dihadapi lembaga pendidikan pada pembelajaran daring adalah dukungan fasilitas koneksi internet yang terbatas. Pihak sekolah mengupayakan penggunaan dana BOS yang dibeikan pemerintah untuk bisa menutupi pembiayaan lembaga terkait pengolahan media pembelajaran berbasis digital, mulai dari pemasangan jaringan internet, alat pendukung pembelajaran daring sampai pada pembagian kuota kepada peserta didik. Hal ini dirasakan perlu karena tanpa dukungan dana, pengadaan barang dan jasa tidak bisa optimal.

Penggunaan dana BOS memang harus tetap sasaran dan penggunaannya harus mengacu pada Rencana Anggaran Pendapatan dan Belanja Sekolah (RAPBS). Pada pelaksanaannya pun harus memegang 
prinsip akuntabilitas dan transparansi yang jelas (Eksantoso, 2020).

\section{Hambatan Dalam Strategi dan Solusi Kepala Sekolah Pada Pembelajaran Daring Selama Pandemi Covid 19}

Pada pelaksanaan pembelajaran selama pandemi Covid 19, adanya partisipasi dari semua pihak di satuan pendidikan adalah hal yang utama. Kepala sekolah perlu mennjalin hubungan kemitraan dengan semua masyarakat sekolah untuk tercapainya pembelajaran daring yang efektif dan efisien. Adapun beberapa kendala yang dihadapi diantaranya sebagai berikut :

1. Sumber Daya Manusia

Dalam sebuah lembaga pendidikan, terdiri dari kepala sekolah, guru dan tenaga kependidikan yang kemampuannya bermacam-macam, dengan keahlian dibidang teknologi informasi yang tidak merata. Lama proses mempelajari teknologi informasi antara personil satu dengan yang lain berbeda-beda. Hal ini menjadi tantangan tersendiri bagi kepala sekolah untuk memberikan dan menyiapkan instruktur pendamping yang akan membantu penyelesaian permasalahan teknis yang dialami oleh para guru pada saat pembelajaran daring.

Sumber daya manusia merupakan salah satu pihak memiliki tanggung jawab dalam menghubungkan informasi antara lembaga pendidikan dengan lingkungan masyarakat. Jika SDM tersebut masih terfragmen-fragmen maka tujuan organisasi akan lebih sulit tercapai dan justru akan menjadi tekanan tersendiri bagi organisasi jika tidak segera diatasi (Mangkuprawira, 2003). Kepala sekolah memiliki fungsi strategis pada kinerja SDM yang meliputi pada proses perencanaan, pengorganisasian, pelaksanaan dan pengawasan (Sandela, 2019).

2. Heterogenitas wali murid

Berbagai macam tanggapan dari wali murid atas perubahan metode pembelajaran dari tatap muka ke daring memang tidak dapat dihindari. Masih ada saja wali murid yang tidak peduli pada pembelajaran daring yang memang membutuhkan peran orang tua dirumah untuk mendampingi proses belajar anak. Wali murid tidak berkenan memberikan dukungan waktu dan tenaga bagi keberlangsungan pembelajaran daring dengan alasan memiliki kesibukan, sehingga pembelajaran anak sepenuhnya dikembalikan ke pihak sekolah. Kurangnya kesadaran wali murid untuk berpartisipasi menjadi suatu tantangan yang perlu didiskusikan jalan keluarnya demi keharmonisan sekolah dan wali murid (Daswirman, 2019).

Wali murid merupakan bagian dari kesatuan sekolah yang memiliki hubunugan antar satu dengan yang lan saling berkaitan. Jika dalam hubungan tersebut terjalin hubungan yang erat dan saling kerjasama maka proses organisasi akan mudah dilaksanakan. Sebaliknya jika ada kebuntuan dalam hubungan tersebut akan membawa konflik tersendiri yang akan menurunkan produktivitas sebuah organisasi (Indrawijaya, 2000).

3. Keterbatasan dana

Telah dipahami bahwa membangun insfrastruktur memang membutuhkan pembiayaan yang tidak sedikit, termasuk pembangunan sistem pendukung pembelajaran daring ini. Artinya jika pendanaan murni diharapkan dari pihak pemerintah ataupun sekolah, maka bisa jadi tidak bisa mengcover semua kebutuhan. Solusinya adala, menekankan pada prioritas kebutuhan utama yang akan dipenuhi terlebih dahulu.

Dana pembiayaan merupakan salah satu aspek penting dalam penyelenggaraa pendidikan, karena melalui pembiayaanlah adanya cukupan kebutuhan operasional sebuah lembaga. Sebuah pembiayaan hendaklah sesuai dengan sesuai perencanaan dan pemanfaatannya sesuai dengan kebutuhan dan peraturan 
perundang-undangan (Sutarman \& Asih, 2016).

4. Komunikasi

Pembelajaran daring membawa permasalahan tersendiri dalam kaitannya dengan komunikasi antara guru dan murid. Pada pembelajaran daring, lebih menekankan pada komunikasi secara verbal, padahal keikutsertakan emosi dan perasaan pada proses pembelajaran uga menjadi hal yang penting dalam mencapai hasil yang optimal. Kondisi seperti ini menyebabkan mudah sekali ketidaksesuaian dan kesalahpahaman antara guru dan peserta diik saat proses pembelajaran berlangsung. Komunikasi persuasif guru sangatlah penting dalam penerapan pembelajaran daring (Puspitasari \& Noor, 2020).

Guna meminimalisasi kendala dalam hal komunikasi adalah meminimalkan penggunaan kata atau kalimat dalam sebuah informasi yang bias atau memilihkan padakan kata dan kalimat yang mudah dipahami, sehingga si penerima pesan bisa memahami tanpa memiliki persepsi yang berbeda-beda (Mulyana, 2016).

\section{KESIMPULAN DAN REKOMENDASI}

Menyikap pembelajaran daring saat pandemi Covid 19, sangat penting bagi kepala sekolah untuk memiliki strategi solutif agar pembelajaran tetap bisa optimal. Kepala Sekolah mengambil langkah pengembangan potensi para guru melalui pelatihan-pelatihan bagi SDM, penyediaan layanan ekstrakulikuler online bagi peserta didik, mempersiapkan perangkat pembelajaran yang memadai pembelajaran dan optimalisasi penggunaan dana BOS. Adapun kendala yang dihadapi pada implementasi strategi solutif kepala sekolah pada pembelajaran daring saat pandemi Covid 19 adalah faktor SDM, heterogenitas wali murid, keterbatasan dana dan komunikasi. Menyikapi hal tersebut Kepala Sekolah mengambil kebijakan untuk pengembangan kompetensi SDM, relaksasi pembiayaan keuangan serta membuka melalui forum komunikasi dua arah antara wali murid dan sekolah.

\section{KEPUSTAKAAN ACUAN}

Ahmadi, A., \& Supriyono, W. (2008). Psikologi Belajar. PT. Rineka Cipta.

Asrori, M. (2009). Psikologi Pembelajaran. CV . Wacana Prima.

Daswirman, D. (2019). Kontribusi Kompetensi Manajerial Kepala Sekolah Dan Peran Komite SekolahTerhadap Ketersediaan Sarana Labor IPA Pada SMPN Di Kota Sawah Lunto. Al-Fikrah: Jurnal Manajemen Pendidikan, 7(1), 33-44.

Dedi, D. (2019). Manajemen Kepala Sekolah Dalam Membentuk Kepribadian Siswa Di SDN 31 Batu Bulek Kecamata Lintau Buo Utara. Al-Fikrah: Jurnal Manajemen Pendidikan, 7(2), 97-106.

Dimyati, D., \& Mudjiono, M. (2015). Belajar Dan Pembelajaran. PT. Rineka Cipta.

Eksantoso, S. (2020). Peningkatan Akuntabilitas Pengelolaan Dana Biaya Operasional Sekolah (BOS). ADIKARA CENDEKIA: Jurnal Ilmiah Pendidikan Dan Pembelajaran, 1(1), 1-11.

Fattah, N. (2013). Sistem Penjaminan Mutu Pendidikan. PT. Remaja Rosdakarya.

Firdaus, A., \& Aslinda, A. (2021). Strategi Pengembangan Manajemen Peserta Didik Dalam Meningkatkan Mutu Pendidikan Di MTsN Padang Panjang. Al-Fikrah: Jurnal Manajemen Pendidikan, 8(2), 95-106.

Ghony, M. D., \& Almanshur, F. (2017). Metodologi Penelitian Kualitatif. Ar-Ruzz Media.

Hasibuan, M. S. P. (2012). Manajemen Sumber Daya Manusia. CV. Bumi Aksara.

Hidayatullah, S., Khouroh, U., Windhyastiti, I., Patalo, R. G., \& Waris, A. (2020). Implementasi Model Kesuksesan Sistem Informasi DeLone And McLean Terhadap Sistem Pembelajaran Berbasis Aplikasi Zoom Di Saat Pandemi Covid19. Jurnal Teknologi Dan Manajemen 
Informatika, 6(1), 44-52.

Indrawijaya, A. I. (2000). Perilaku Organisasi. Sinar Baru Algesindo.

Irtiqo, N. (2017). Peran kepemimpinan kepala sekolah dalam meningkatkan motivasi kinerja guru di TK Tunas Adipura Surabaya. Inspirasi Manajemen Pendidikan, 5(1).

Kemendikbud. (2020). Surat Edaran Nomor 15 Tabun 2020 tentang Pedoman Penyelenggaraan Belajar Dari Rumah Dalam Masa Darurat Penyebaran Corona Virus Deseas (COVID-19). https://dispendik.surabaya.go.id/pengu muman/2020/surat-edaran-nomer-15tahun-2020-tentang-pedomanpenyelenggaraan-belajar-dari-rumah/

Khairuddin, K. (2020). Kepemimpinan Kepala Sekolah Di Tengah Pandemi Covid 19. Edukasi, 8(2), 171-183.

Maiza, Z., \& Nurhafizah, N. (2019). Pengembangan Keprofesian Berkelanjutan dalam Meningkatkan Profesionalisme Guru Pendidikan Anak Usia Dini. Jurnal Obsesi: Jurnal Pendidikan Anak Usia Dini, 3(2), 356-465.

Mangkuprawira, T. S. (2003). Manajemen Sumber Daya Manusia Strategik. Ghalia Indonesia.

Miles, M. B., \& Huberman Johnny, A. M. S. (2014). Qualitative Data Analysis: A Methods Sourcebook Third Edition. Sage Publications.

Mulyana, D. (2016). Ilmu Komunikasi: Suatu Pengantar. PT. Remaja Rosdakarya.

Murniati, A. R. (2008). Manajemen Stratejik: Peran kepala sekolah dalam pemberdayaan. Perdana Publishing.

Nahdi, D. S., \& Jatisunda, M. G. (2020). Analisis literasi digital calon guru SD dalam pembelajaran berbasis virtual classroom di masa pandemi covid-19. Jurnal Cakerawala Pendas, 6(2).

Noor, T. R. (2017a). Analisis Desain Fasilitas Umum Bagi Penyandang Disabilitas (Sebuah Analisis Psikologi Lingkungan). Journal An-Nafs: Kajian Penelitian Psikologi, 2(2), 133-150. https://doi.org/10.33367/psi.v2i2.438
Noor, T. R. (2017b). Manajemen Pendidikan Anak Melalui Program Outbound Di TK Al Muslim Surabaya. SELING: Jurnal Program Studi PGRA, 3(2), 64-75. https://doi.org/10.29062/seling.v3i2.12 0

Noor, T. R. (2017c). Upaya Guru Dalam Menanamkan Nilai Agama di KB Al Muslim Surabaya. Edusiana: Jurnal Manajemen Dan Pendidikan Islam, 4(1), 46-57. https://doi.org/10.30957/edusiana.v4i1. 7

Noor, T. R. (2019). Pendidikan Islam Sebagai Sebuah Sistem Di Era 4.0. TA'LIM: Jurnal Studi Pendidikan Islam, 2(2), 153171.

https://doi.org/10.29062/ta'lim.v2i2.14 72

Noor, T. R. (2020a). Alternatif Pemecahan Masalah Pada Masyarakat Multikultural. Al Iman: Jurnal Keislaman Dan Kemasyarakatan, 4(2), 204-232.

Noor, T. R. (2020b). Bibliotherapy Sebagai Upaya Meningkatkan Keterampilan Interpersonal Remaja. Jurnal Studia Insania, $\quad$ 8(2), 164-182. https://doi.org/10.18592/jsi.v8i2.3974

Osreni, O. (2020). Peran Gaya Kepemimpinan Kepala Sekolah Dalam Meningkatkan Kinerja Guru Dan Mutu Sekolah (Studi Kasus di SD Negeri 02 BatipuhKecamatan Batipuh Selatan). AlFikrah: Jurnal Manajemen Pendidikan, 8(1), 29-38.

Puspitasari, A., \& Noor, T. R. (2020). Optimalisasi Manajemen Pembelajaran Daring dalam Meningkatkan Adversity Quotient (AQ) Siswa Selama Pandemi Covid-19. Jurnal Elkatarie: Jurnal Ilmu Pendidikan Dan Sosial, 3(2), 439-458. https://doi.org/10.1234/elkatarie.v3i2.4 019

Rigianti, H. A. (2020). Kendala Pembelajaran Daring Guru Sekolah Dasar di Banjarnegara. Elementary School: Jurnal Pendidikan Dan Pembelajaran Ke-Sd-An, 7(2), 297-302. 
Rohmah, N. (2017). Peran Kepala Sekolah Dalam Melakukan Kontrol Mutu Pendidikan. Tarbiyatuna: Jurnal Pendidikan Imiah, 2(1), 148-180.

Rusdarti, R., Slamet, A., \& Prajanti, S. D. W. (2019). Pengembangan Keprofesian Berjelanjutan Dalam Pembuatan Pulblikasi Ilmiah Dan Workshp Dan Pendampingan bagi Guru SMA Kota Semarang. Rekayasa: Jurnal Penerapan Teknologi Dan Pembelajaran, 16(2), 271280.

Rusdiana, A. (2016). Pengembangan Organisasi Lembaga Pendidikan. CV. Pustaka Setia.

Sagala, S. (2013). Manajemen Strategik Dalam Peningkatan Mutu Pendidikan. CV. Alfabeta.

Saifulloh, A. M., \& Darwis, M. (2020). Manajemen Pembelajaran dalam Meningkatkan Efektivitas Proses Belajar Mengajar di Masa Pandemi Covid-19. Bidayatuna: Jurnal Pendidikan Guru Mandrasah Ibtidaiyah, 3(2), 285-312.

Sandela, M. (2019). Manajemen Rekrutmen Tenaga Pendidik Di SDIT Sa'adiah Kecamatan Kubung Kabupaten Solok. Al-Fikrah: Jurnal Manajemen Pendidikan, 7(2), 155-166.
Sugiyono, S. (2016a). Memahami Penelitian Kualitatif. CV. Alfabeta.

Sugiyono, S. (2016b). Metode Penelitan Pendidikan: Pendekatan Kuantitatif, Kualitatif dan R\&D. CV. Alfabeta.

Sutarman, M., \& Asih, A. (2016). Manajemen Pendidikan Usia Dini: Filosofi, Konsep, Prinsip dan Aplikasi. PT. Pustaka Setia.

Syah, M. (2016). Psikologi Pendidikan Dengan Pendekatan Baru. PT. Remaja Rosdakarya.

Utami, S. F., Suarantalla, R., \& Hermanto, K. (2020). Analisis Beban Kerja Mental Guru Sekolah Dasar Menggunakan Metode NASA-TLX Studi Kasus di SDN Batu Tering. Jurnal Industri \& Teknologi Samawa, 1(2), 14-18.

Wahyudi, I. (2012). Pengembangan Pendidikan: Strategi Inovatif dan Kreatif dalam Mengelola Pendidikan Secara Komprehensif. PT. Prestasi Pustakaraya.

Hasil Wawancara dengan Kepala SDN Sumput, Sidoarjo 17 Desember 2020 Pukul 07.56 WIB. (n.d.).

Hasil Wawancara dengan Sekretaris SDN Sumput, Sidoarjo 18 Desember2020 Pukul 07.30 WIB. (n.d.). 